\title{
RET/NCOA4 Fusion Gene
}

National Cancer Institute

\section{Source}

National Cancer Institute. RET/NCOA4 Fusion Gene. NCI Thesaurus. Code C99849.

A fusion gene that results from a paracentric inversion inv(10)(q11q11) which fuses the $5^{\prime}$ portion of the RET gene and the 3' portion of the NCOA4 gene. This rearrangement is associated with papillary thyroid carcinoma. 